\title{
Wederopbouwwijken verdienen beter
}

AUTEURS Hanneke Posthumus \& Annelies Beek

FOTOGRAFIE Annelien Meerts

\section{Waar wederopbouwwijken (1945-1973) ooit een oplossing waren, worden zij nu vaak als probleem bestempeld. Bij de kwaliteiten van wederopbouw- wijken en de kansen die zij in de toekomst bieden, wordt maar mondjesmaat stilgestaan. Tijd voor een tegengeluid.}

Groningen in de jaren zestig. De bevolking neemt in rap tempo toe. De stad heeft een grote aantrekkingskracht als economische motor van het Noorden die nog eens wordt versterkt door de maatregelen van het Rijk om de bevolkingsdruk op de Randstad te verlichten. Een nijpend woningtekort is het gevolg. Om dit probleem het hoofd te bieden wordt in 1961 het structuurplan van H.J. Dix en H. Eysbroek aangenomen. Een plan met een marktgerichte ontwerpstrategie: door aan de rand van de stad uitbreidingswijken te realiseren zou Groningen van een stad met 147.766 inwoners in 1961 tot een stad met maar liefst 265.000 inwoners in 2000 kunnen uitgroeien. Eén van deze uitbreidingswijken is Paddepoel. Een wijk met meer dan 4.500 woningen die allemaal in een periode van slechts vier jaar, tussen 1965 en 1968, zijn opgeleverd. De verkavelingspatronen zijn gestandaardiseerd en geven de wijk de voor de wederopbouwperiode zo kenmerkende gestempelde bebouwingsstructuur omzoomd met groene zones. De winkels zijn geconcentreerd in het lokale winkelcentrum. Na oplevering is de wijk een gewilde locatie onder gezinnen uit de middenklasse.

In de loop der jaren is de populariteit van deze wijk afgenomen. Veel bewoners van het eerste uur vertrokken en werden opgevolgd door minder welvarende bewoners. De culturele diversiteit in de wijk nam toe en de woningen konden steeds minder goed aan de moderne standaarden voldoen. Ook nam de bedrijvigheid in het winkelcentrum op sommige vlakken af: waar er ooit drie supermarkten waren is er nu nog maar één. Paddepoel kreeg een slechte naam en werd gezien als een probleemwijk.
Rond de eeuwwisseling vonden de gemeente, corporaties en welzijnsorganisaties het tijd voor verandering en besloten de wijk aan te pakken. Ingrijpende maatregelen werden niet geschuwd. Verschillende complexen gingen tegen de vlakte om plaats te maken voor nieuwbouw. De bouw van duurdere koopwoningen, waaronder zo af en toe zelfs een heuse penthouse, moest niet alleen de fysieke kwaliteit van de wijk verbeteren, maar ook beter bedeelde bewoners naar de wijk lokken.

Het levensverhaal van Paddepoel zal $\mathrm{u}$ - als geïnteresseerde in sociaalruimtelijke vraagstukken - niet vreemd in de oren klinken. Behalve Paddepoel hebben talloze andere wederopbouwwijken ditzelfde traject doorlopen. Waar zij ooit zelf oplossingen voor een probleem waren, zijn wederopbouwwijken nu het probleem waar een oplossing voor moet worden gevonden.

Toch wordt het negatieve beeld van Paddepoel niet door iedereen gedeeld. Uit gesprekken met buurtbewoners van Paddepoel in het kader van het onderzoek 'Bijwerkingen van herstructureringsoperaties' blijkt dat zij dikwijls een veel positiever beeld hebben. Zo zegt een bewoonster die al veertig jaar in de wijk woont: "Ik zit hier ontzettend gunstig ten opzichte van het centrum, er gaan twee buslijnen heel vaak die kant op. En het winkelcentrum heeft een Hema, Albert Heijn, bakkers en slagers. Dus wat wil ik nog meer." Een ander benadrukt hoe fijn de sociale contacten zijn: "Ik vind het prettig zoals we met elkaar omgaan, dat je elkaar een dienst kunt vragen. Laatst was er een mevrouw uit de flat in het winkelcentrum onderuit gegaan. Dan bellen de buren even op of ze iets kunnen doen, boodschapjes halen...". Hoewel de bewoners van Paddepoel ook erkennen dat hun wijk problemen kent, benadrukken zij vaak juist de positieve kenmerken van hun wijk. Zij laten daarmee zien dat het te kort door de bocht is om de wijk enkel en alleen als probleemwijk te bestempelen.

Het positieve geluid dat bewoners uit Paddepoel en andere wederopbouwwijken laten horen is echter slechts een zwak geroeze- 


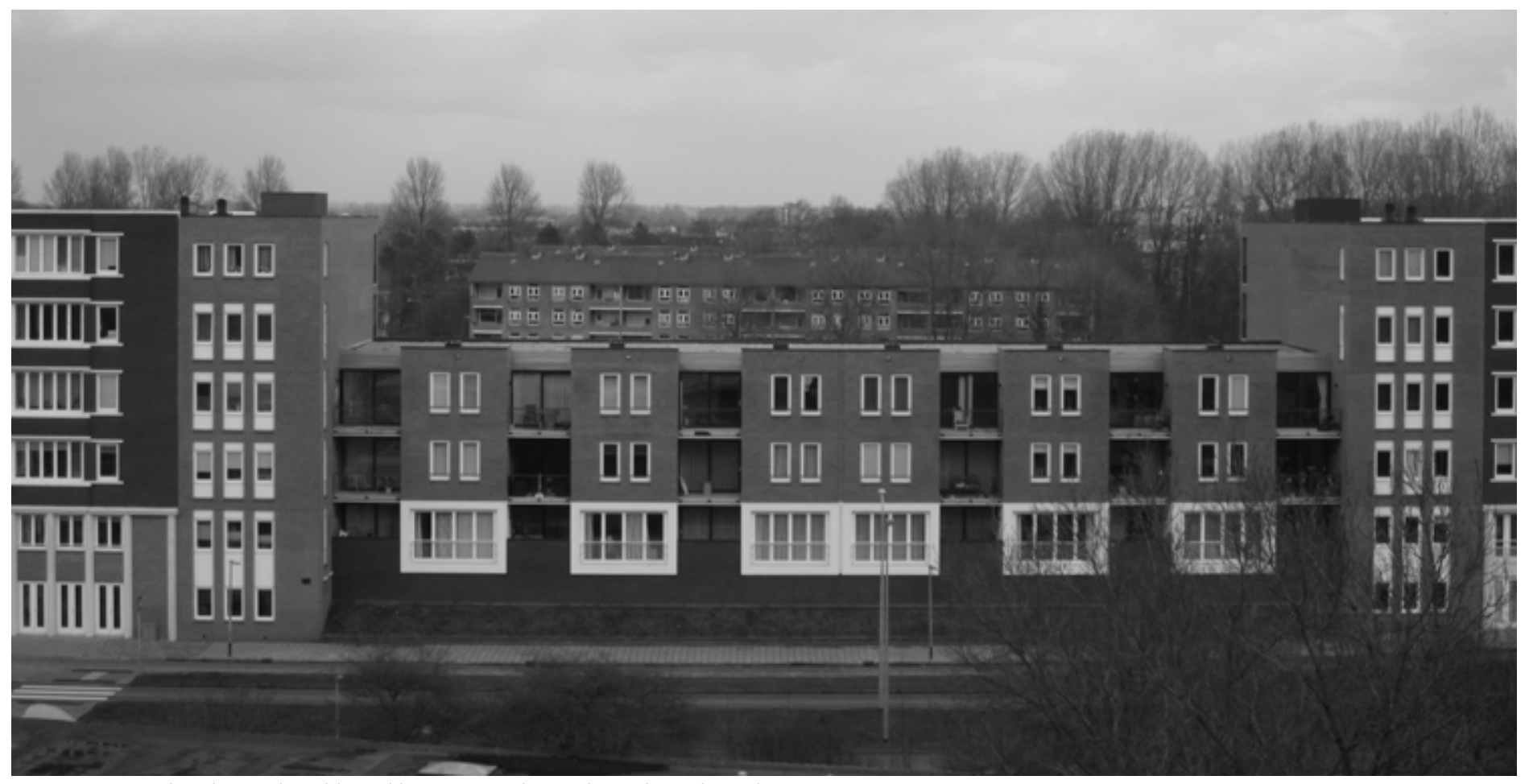

De Groningse uitbreidingswijk Paddepoel ligt nog steeds aan de rand van de stad

moes vergeleken met de schreeuwerige en alarmerende toon die in de berichtgeving over wederopbouwwijken domineert. Bij de kwaliteiten die wederopbouwwijken - nu en in de toekomst - hebben wordt zelden stil gestaan. In dit nummer besteedt AGORA aandacht aan de kansen en kwaliteiten van deze wederopbouwwijken; wijken die opgeleverd zijn tussen grofweg 1945 en 1973.

Allereerst door stil te staan bij de planningstraditie achter wederopbouwwijken, welke bepalend is geweest voor zowel de problemen als de kwaliteiten in de wijken. Michiel Overkamp gaat in zijn artikel in op de ruimtelijke structuur van deze wederopbouwwijken.

\section{Het positieve geluid dat bewoners laten horen is slechts een zwak geroezemoes}

Wederopbouwwijken kunnen getypeerd worden als functionalistische wijken die gebaseerd zijn op het CIAM (Congrès Internationaux d'Architecture Moderne) -gedachtegoed. Het doel van oprichter Le Corbusier was ambitieus: het vinden van een ideale structuur voor wijken, om bewoners een prettige woonomgeving te bieden. 'Licht, lucht en ruimte' en de wijkgedachte zijn de twee bepalende principes voor deze wijken. Anita Blom ziet deze principes als de cultuurhistorische aspecten van wederopbouwwijken. Haar artikel is een pleidooi voor herwaardering en in het bijzonder voor het aanwijzen van cultuurhistorisch erfgoed in deze wijken. Waarom wordt er geen cultuurhistorisch erfgoed aangewezen in de wederopbouwwijken, terwijl dat wel gebeurt in de historische binnensteden? Deze wijken zijn immers bepalend geweest voor de succesvolle opbouw van ons land na de Tweede Wereldoorlog. Eindelijk konden veel mensen een gedeelde bovenwoning in de binnenstad verruilen voor een ruime eigen woning in het groen.

Het vele groen in wederopbouwwijken maakt onderdeel uit van de functionalistische structuur en kan gezien worden als een kracht van deze wijken, oftewel het groene kapitaal. Stedenbouwkundigen en landschapsarchitecten besteedden veel zorg aan het groen in wederopbouwwijken. Toch zijn de doelen van de stedenbouwkundigen en landschapsarchitecten niet behaald. Zo is het gebruik van het groen door de huidige bewoners extensief. Ook is de huidige inrichting van het groen, door bezuinigingen, eenvormig. Door te investeren in de samenhang van het groen kan volgens Yttje Feddes het imago van wederopbouwwijken verbeterd worden, en bijdragen aan de realisatie van de oorspronkelijke gedachte van 'licht, lucht en ruimte'.

Ondanks dat de relatie tussen de inrichting van de ruimte en het groen en menselijk gedrag nog steeds centraal staan in de planologie, is men inmiddels teruggekomen van het idee van een maakbare samenleving dat in de wederopbouwperiode domineerde. Anna de Jong laat in een beeldverhaal zien dat niet alles te plannen valt en dat het functionalisme ook onvoorspelbare effecten heeft. Zo is het gebruik van de ruimte niet alleen voorbehouden aan de menselijke bewoners. Vogels houden geen rekening met het strakke decor dat door planologen is geschapen, maar gaan hun eigen weg.

Behalve de groenzones zijn de wijkwinkelcentra tekenend voor de strikte functiescheiding die in wederopbouwwijken is toegepast. Bewoners hoefden hierdoor geen grote afstand af te leggen voor de dagelijkse boodschappen. In de rest van de wijk lijken weinig economische activiteiten plaats te vinden. Volgens Anne Risselada en Emma Folmer is de werkelijkheid genuanceerder en is de bedrijvigheid soms onzichtbaar. In hun artikel gaan zij aan de hand 
van een vergelijking van vooroorlogse, vroeg- en laat-naoorlogse wijken verder in op de rol van de stedelijke structuur voor de economische potentie van wijken.

Hoewel de ruimtelijke structuur bepalend is voor het aanzien van een wijk, worden wijken niet gebouwd om stedenbouwkundige en planologische idealen over wederopbouwwijken te realiseren, maar om bewoners een thuis te bieden. In een themanummer mogen de bewoners dan ook niet ontbreken. Zij zijn immers de gebruikers van de ruimte. In onderzoeken naar wederopbouwwijken wordt vaak gesproken over de ontevredenheid van de bewoners met hun wijk. Er zijn echter ook positieve geluiden te horen, zoals in de wijk Paddepoel. Ook Kirsten Visser laat zien dat jongeren - een veronderstelde probleemgroep - vaak juist trots zijn op hun wijk. Voor hen vormt de wijk een plek waar ze zich thuis voelen en waar ze andere jongeren kunnen ontmoeten. Op welke manier kunnen we deze wijkbinding van jongeren inzetten voor de toekomst van de wijk? Behalve dat de auteurs in deze AGORA de kansen benoemen die wederopbouwwijken bieden, onderkennen zij ook de problemen. Om de kansen te benutten moet er daarom wel wat veranderen. Sociale en fysieke ingrepen in de ruimte kunnen hieraan bijdragen. In de wijkaanpak wordt het antwoord op de problematiek vooral in fysieke aanpassingen van de ruimte gezocht. Klaas Mulder bekritiseert deze aanpak en betoogt dat deze een te statistische benadering hanteert. De wijkaanpak kan de situatie in wijken verbeteren, maar daarbij moet gekeken worden naar de persoonlijke functioneringsvraagstukken van de bewoners van de wijk.

Naast sociale ingrepen pleiten de auteurs in deze AGORA ook voor fysieke ingrepen. Volgens Tineke Lupi en Frank Wassenberg kunnen wederopbouwwijken meer profiteren van de basiskwaliteiten. Zo wijzen zij op de kwaliteit van de locatie van wederopbouwwijken, tussen het centrum en de VINEX-wijken. Ook Arjan Hebly ziet vernieuwing van wederopbouwwijken die gebaseerd is op de eigen kwaliteiten als het meest duurzaam. Hij pleit voor kleinschalige projecten als onderdeel van accumulerende stadsvernieuwing. Daardoor wordt de wijk na iedere ingreep verbeterd en kan de aanpak op ieder moment getemporiseerd worden. Ook volgens Lupi en Wassenberg kunnen sociale en fysieke ingrepen niet succesvol zijn zonder een ander proces van planning. Incrementele planning, minder strikte regelgeving, meer flexibiliteit en meer ruimte aan burgers en markt maken hier onderdeel vanuit.

De bijdragen aan deze AGORA onderschrijven het idee dat het negatieve beeld over wederopbouwwijken genuanceerd moet worden. Dit kan alleen veranderen door de kwaliteiten van wederopbouwwijken te onderkennen en te benutten. Deze AGORA biedt handreikingen voor deze opgave.

\section{Hanneke Posthumus is promovenda en Annelies Beek is docente aan de Factulteit Geowetenschappen van de Universiteit Utrecht. Beiden zijn eveneens redacteurs van AGORA.}

Literatuurselectie

Posthumus, H., Kleinhans, R. \& Bolt, G. (2012). Bijwerkingen van herstructureringsoperaties. Verhuizingen, waterbedeffecten en veranderingen in de woningvoorraad. Delft: Eburon.

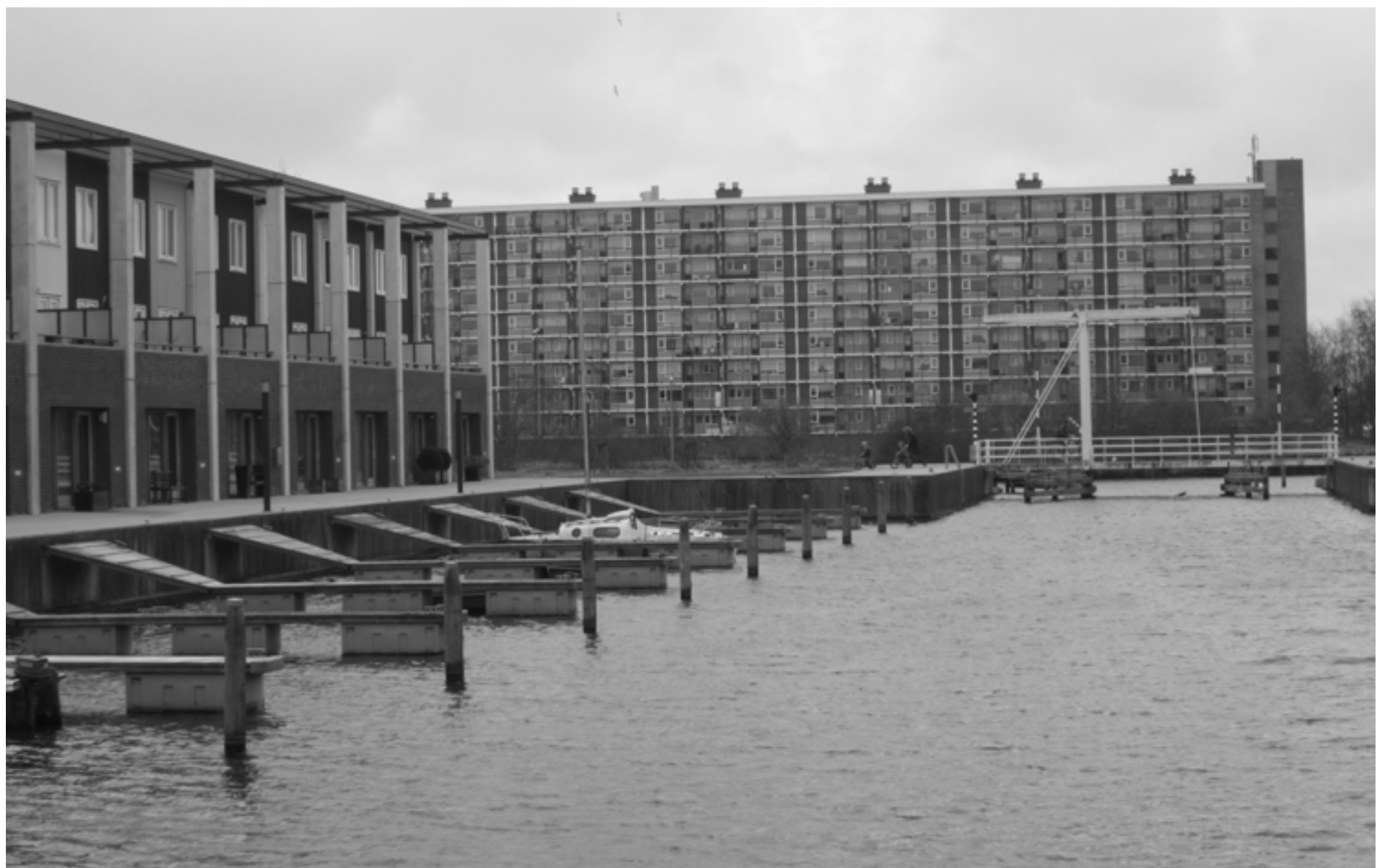

Na herstructurering staan koop- en sociale huurwoningen zij aan zij in Paddepoel 